\title{
Impact analysis of e-Databases' job relevance, output quality and result demonstrability on faculty research motivation
}

\author{
Roland Izuagbe and Olajumoke Rebecca Olawoyin \\ University Library, Covenant University, Ota, Nigeria \\ Christopher Nkiko \\ University Library, Elizade University, Ilara-Mokin, Nigeria \\ Promise Ifeoma Ilo \\ University Library, Pamo University of Medical Sciences, Port Harcourt, Nigeria, and \\ Felicia Yusuf, Mercy Iroaganachi, Julie Ilogho and \\ Goodluck Israel Ifijeh \\ University Library, Covenant University, Ota, Nigeria
}

\begin{abstract}
Purpose - The purpose of the study is to ascertain whether or not faculty members would be motivated to use e-Databases for research considering the impact of the Technology Acceptance Model2 (TAM2) cognitive instrumental processes of job relevance, output quality and result demonstrability.

Design/methodology/approach - The survey research design was applied. The selection of samples was based on a multistage sampling technique involving; purposive, simple/systematic random and total enumeration procedures. Five colleges and departments each were selected from the three universities that provided the setting for the conduct of this study, out of which a sample of 135 was drawn from the total population of 209. The questionnaire method was used for data gathering. Ninety-five percent return rate of the administered instrument was observed. Descriptive and inferential statistical tools were employed for data analyses.

Findings - Job relevance, output quality and result demonstrability are motivators of faculty use of e-Databases for research with result demonstrability wielding the strongest influence. Use of e-Databases for research is based on the usefulness level perceived of them. Faculty are highly predisposed to using the technology for research with the chances of getting published in reputable journal outlets ranked highest among other factors that influence faculty use of e-Databases.

Originality/value - The conceptualization of TAM2 cognitive instrumental processes as system characteristics and motivators of e-Databases use among faculty towards research engagement advances the understanding of intention to use e-Databases for research.
\end{abstract}

Keywords e-Databases, Job relevance, Output quality, Result demonstrability, Research motivation,

Cognitive instrumental processes

Paper type Research paper

C Roland Izuagbe, Olajumoke Rebecca Olawoyin, Christopher Nkiko, Promise Ifeoma Ilo, Felicia Yusuf, Mercy Iroaganachi, Julie Ilogho and Goodluck Israel Ifijeh. Published by Emerald Publishing Limited. This article is published under the Creative Commons Attribution (CC BY 4.0) licence. Anyone may reproduce, distribute, translate and create derivative works of this article (for both commercial and noncommercial purposes), subject to full attribution to the original publication and authors. The full terms of this licence may be seen at http://creativecommons.org/licences/by/4.0/legalcode

The Covenant University Centre for Research, Innovation, and Development (CUCRID), Covenant University, Ota, Nigeria provided full sponsorship for the publication of this work.

e-Databases and faculty research motivation

Received 24 January 2020

Revised 27 April 2020

24 September 2020 